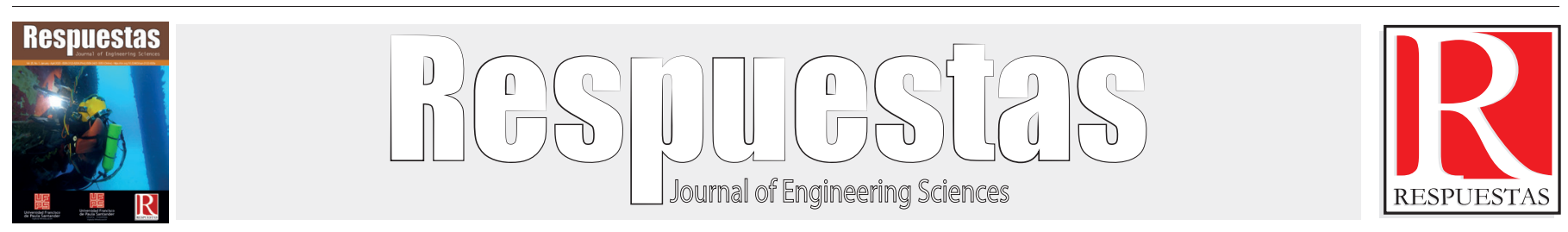

Original Article

https://doi.org/10.22463/0122820X.1830

\title{
Emissions from surrounding strata in coalbeds: Guaduas formation (Colombia)
}

\author{
Emisiones de las rocas circundantes a los mantos de carbon: formación Guaduas (Colombia)
}

Jorge Eliecer Mariño-Martinez ${ }^{*}$

I*PhD Geología; Jorge.marino@uptc.edu.co; Orcid: 0000-0001-5105-2095, Universidad Pedagógica y Tecnológica, Tunja, Colombia.

How to cite: J.E Mariño-Martinez, "Emissions from surrounding strata in coalbeds: Guaduas formation (Colombia)". Respuestas, vol. 25, no. 1, pp. 44-52, 2020.

Received on June 11, 2019; Approved on November 3, 2019

\begin{tabular}{ll}
\hline ABSTRACT \\
\hline Keywords: & $\begin{array}{l}\text { During underground coal mining operations, greenhouse gas emissions are produced, mainly methane. These } \\
\text { emissions originated not only from coal, but also from the subsidence of the surrounding rocks. Until now, } \\
\text { emissions from surrounding rocks have been calculated from international tables, but it is proposed that } \\
\text { they be calculated from gas measurements on coal-adjacent rocks in coalbed methane exploration in which }\end{array}$ \\
$\begin{array}{l}\text { Guaduas formation, } \\
\text { emissions, }\end{array}$ & $\begin{array}{l}\text { contents of the surrounding rocks, and thus the emissions, are less than those found in the coal at the same } \\
\text { depth. The areas with the highest gas content values in the surrounding rocks are Samaca and Chinavita }\end{array}$ \\
methane desorption, & with contents between 40 and 50 feet3/ton. These values equate to one-third or a quarter of those obtained \\
surrounding strata, & from the coalbeds close to such samples. The highest gas content did not correspond to the highest coal rank \\
shales, & (Socotá) which would be explained by the intense folding and faulting in that area. The gas contents found \\
GHG, & in the shales (clays) of the Guaduas formation can also be used as a proxy indicator for older and deeper \\
fBM, & formations that could have good shale gas potential.
\end{tabular}

\section{RESUMEN}

\section{Palabras clave:}

formación Guaduas, emisiones, desorción de metano, rocas circundantes, lodolitas,

GEI,

CBM,

Colombia.
Durante las operaciones de minería subterránea de carbón se producen emisiones de gases de efecto invernadero, principalmente metano. Esas emisiones no solamente proceden del carbon, sino también de la subsidencia de las rocas circundantes. Hasta ahora los cálculos de las emisiones de las rocas circundantes se han hecho a partir de tablas internacionales, pero se propone que se hagan a partir de las mediciones de gas en las rocas adyacentes al carbon en estudios con perforaciones de gas asociado al carbon en los departamentos de Boyacá y Cundinamarca en los que se utilizaron equipos de desorción cánisters. Los contenidos de gas de las rocas circundantes, y por ende las emisiones, son menores a las encontradas en el carbon a la misma profundidad. En las zonas con los valores más altos en contenido de gas en las rocas circundantes son Samacá y Chinavita donde se encontraron contenidos entre 40 y 50 pies3/tonelada. Esos valores equivalen a una tercera o cuarta parte de los que se obtuvo de los carbones cercanos a dichas muestras. Los contenidos de gas más altos no correspondieron con la zona de mayor rango de los carbones (Socotá) lo que se explicaría por el intenso plegamiento y fracturamiento de dicha zona. Los contenidos de gas encontrados en las arcillas (shales) de la formación Guaduas también se pueden utilizar como un indicador (proxy) para formaciones más antiguas y profundas que podrían tener un buen potencial de shale gas. 


\section{Introduction}

During coal mining operations, there are greenhouse gas (GHG) emissions not only from the mining of the coal seams, but also from the subsidence of the surrounding strata. These GHGs are methane (CH4), carbon dioxide (CO2) and others, but mainly $\mathrm{CH} 4$. The Intergovernmental Panel on Climate Change (IPCC) has considered that, during the extraction of coal seams, the rocks surrounding the coal seams also emit methane that affects an area $50 \mathrm{~m}$ below and $150 \mathrm{~m}$ above due to the subsidence produced by coal extraction [1]. The total amount of emissions from a coal seam is the emissions from the coal and the emissions from the surrounding strata above and below the coal layers. These emissions from the massif, where the coal is located, are generated by the fracture and sinking of the rocks above the coal, mainly the thin unmined mantle, carbon backs, claystones - mudstones (shales) and sandstones in general.

During the last few years Colombia has been calculating fugitive emissions from coal seams in mining areas (CBM-CMM) using international tables [2]. Fugitive emissions are known by this name because they are not formed by fuel burns, but rather by the escape of gases that are trapped in the rocks and minerals and are emitted into the atmosphere by anthropic action; this happens with the methane gas associated with coal that is emitted into the atmosphere slowly and almost imperceptibly; when the mineral is extracted through the process of exploration, exploitation, storage and transport of coal. Fugitive gas emissions associated with coal mining account for 5 percent of energy-related GHGs [3].

The carbon-associated gas (CBM) studied to date includes Cretaceous-Tertiary bituminous coals, which have been studied using desorption canisters, petrography, physicalchemical and isotope analyses to determine gas content, gas origin, and gas saturation of the coals [4], [5].

Colombia, as a signatory to the United Nations Framework Convention on Climate Change in 2015 (Paris Agreement), committed to measure and report periodically on its greenhouse gas (GHG) emissions. This is why the country has been measuring and reporting emissions in recent years at the sectoral and departmental levels; fugitive emissions from coal seams have also been calculated, measured and reported [2], [6].
Although some emission calculations have been made from the coal range using international tables [6], other calculations have used gas content gradients from CBM-CMM exploration wells [2]. Exploration wells in the eastern Andes have found that CBM-CMM values range from a few $\mathrm{ft} 3 /$ tonne near the surface to more than $200 \mathrm{ft} 3 /$ tonne at depths greater than $500 \mathrm{~m}$ (Figure 1). In some cases, if gas content versus depth is plotted, a direct correlation or increase with depth is found that confirms the increase in CBM with burial, suggesting that when drilling at deeper levels, the gas content would be higher. However, although no direct measurements of $\mathrm{CH} 4$ emissions from the surrounding strata have been reported in Colombia so far, in some of these exploration studies some measurements have been made in mudstones (shales) and sandstones near coal seams to understand the risk of explosions during mining, and these measurements can be used as a proxy to calculate the emissions from the surrounding rocks [7] - [11].

Therefore, the purpose of this study is to report, for the first time, the gas content in the strata surrounding the coal in the Guaduas formation in order to calculate the direct emissions from the strata above and below the coal [12] - [14]. The results of this study may be useful not only for the calculation of emissions, but also to calculate the risk of methane gas explosions in mining-related rock tunnels, and to know the shale gas potential of the Guaduas formation.

\section{Materials and Methods}

Although exploration studies for carbon-associated gas (CBM) have been conducted in many exploration wells in the Cundinamarca and Boyacá Altiplano, only a few mudstone and sandstone samples above and below the carbon have been tested for desorption. The sampled wells are located in the municipalities of Sutatausa, Cucunubá, Samacá, Ráquira, Socotá and Chinavita (Figure 1). In these wells, in addition to measuring the gas content, and making immediate analyses, the degree of maturity of the organic matter was also determined from vitrinite (Ro) reflectance tests (performed on a Leica DM4000P microscope, coupled with a Tidas MSP reflectometer from the UPTC). The immediate analyses included moisture, ash, volatile matter, fixed carbon, calorific value and sulphur content (using thermogravimetric analysis techniques on a TGA-Leco S-14DR analyser). 
Although some mining fronts also took mudstone cores above and below the coal seams, the analysis focused on eight samples taken from seven well (Figure 1) (Table I).

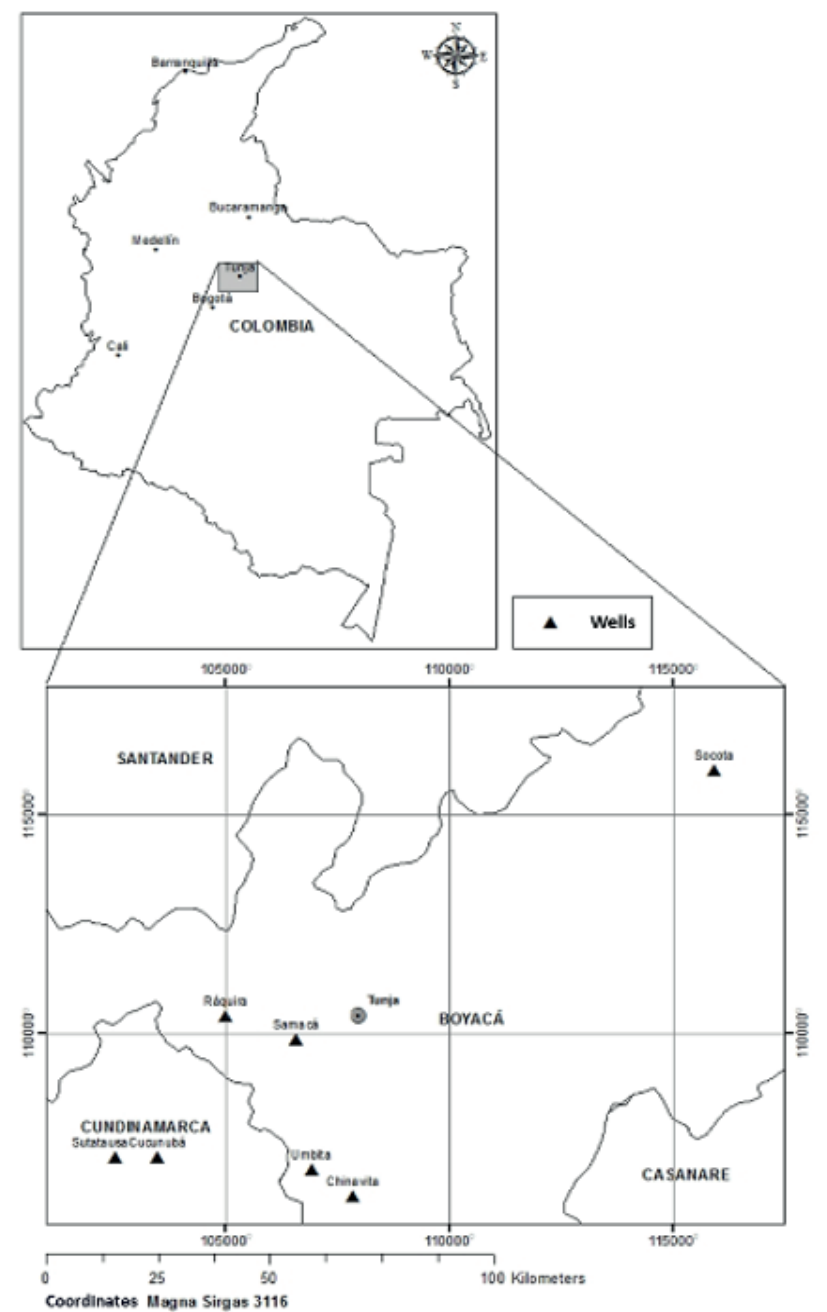

Figure 1. Location of municipalities where coal gas wells were drilled (CBM-CMM)

The gas content in this study is based on direct methods that consist of measuring the amount of gas in a mudstone sample by slowly desorbing the gas from the cores obtained with drilling equipment. Currently, the measurement process comprises three different methodologies taking into account that the total gas content is the sum of three components:

TOTAL GAS CONTENT $(\mathrm{ft} 3 /$ ton $)=$ lost gas + measured gas + residual gas

\section{Lost gas}

It is the gas that escapes in the time since the coal is extracted from its condition in situ and the time it is introduced and sealed inside a canister. For samples taken from mine faces, the gas that escapes during the time between the sample being taken from a mine face and the subsequent sealing within the canister. On the mine front, sampling is similar to the sampling of coal in a carcass. The gas leakage is determined from the extrapolation of the desorption test data during the first two hours of measurement using a linear regression (Figure 3 left). The amount of gas lost can be calculated by the USBM method expressed in $\mathrm{cm} 3 / \mathrm{g}$ or in $\mathrm{ft} 3 /$ ton [4]. 


\section{Measured gas}

This is the amount of gas that a sample of coal or slurry releases in the desorption test with the canister, also known as desorbed gas. The coal samples are placed in sealed canisters or containers; the canister is then connected to a burette to measure the degassing of the coal by opening the valve that allows the gas to escape, which is measured by the displacement of water in a volumetric column in the burette at reservoir temperature and atmospheric pressure [4 and 15]. The difference in levels corresponds to the volume of desorption during that measurement (see Figure 2). The gas desorbed is reported in cubic meters per ton of coal $\left(\mathrm{m}^{3}\right.$ of gas/ton of coal), or also in cubic feet per ton of coal ( $\mathrm{ft}^{3}$ of gas/ton of coal) (Figure 3 Right).

\section{residual gas}

It is the amount of gas that remains absorbed into the carbon matrix after the desorption test has been completed, but is released and measured once the sample has been crushed. The measurement of residual gas is done by removing the coal sample from the canister and splitting it into quarters. One of these parts is taken and placed in a ball or roller mill, the coal is pulverized within 3 to 10 minutes; the container must be hermetically sealed and connected to a pressure gauge to measure the residual gas content.

The determination of the total gas desorbed will correspond to the sum of all the measured volumes (lost, measured and residual) in the three tests, all corrected to standard temperature and pressure (STP) [4].

\section{Gas desorption equipment}

The canister desorption system used to determine the gas content of mudstone samples consists of a cylinder-shaped airtight chamber made of metal or PVC. The container is sealed at one end (base) and a hermetic cap at the other end. The dimensions of the canisters are: length 30-37 $\mathrm{cm}$ and diameter $10-12 \mathrm{~cm}$. At the top, there is a $5-15$ psi gauge, and an additional hole with a tap to connect it to the burette of the gas measuring system (Figure 2). The volume of the containers should be about one litre. In addition to the containers, the measurement of the gas system is determined by the displacement of a column of water consisting of a burette connected to the pipe with a system of hoses. The burette can be $250 \mathrm{ml}$ or more. The assembly is carried out by connecting the two couplings at each end of the burette with the metal bracket so that the burette is completely vertical.

While one end of the burette is connected to the canister, the other end is connected with a flexible hose to a funnel. The burette is filled with coloured water for better observation of the gas movement as it leaves the cannister and pushes the water column (Figure 2).
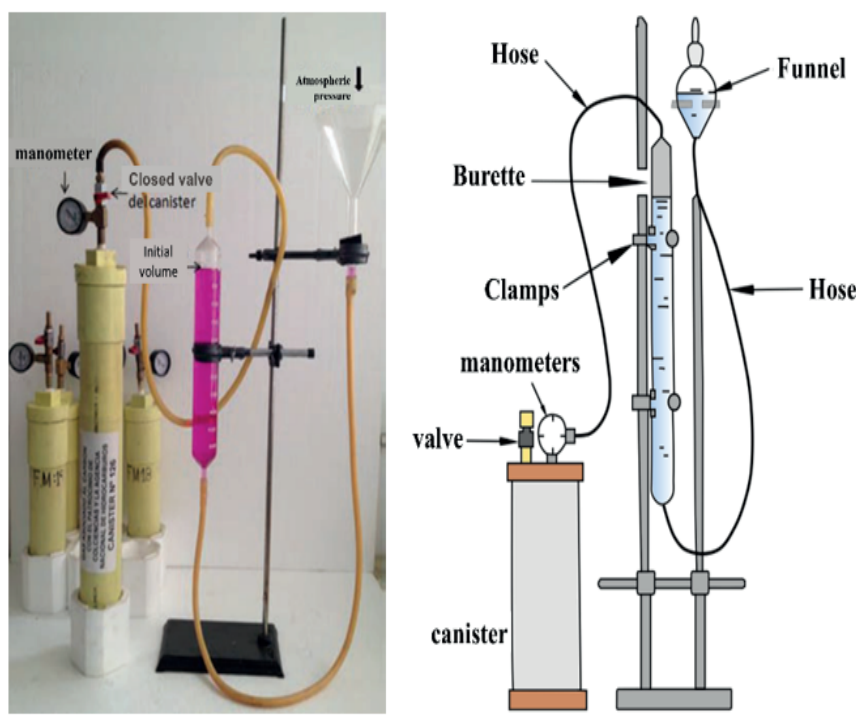

Figure 2. Desorption system with cannisters used to measure gas content.

In addition to recording the centimeters of gas desorbed at each measurement, the time of each measurement, temperature, pressure, and date are also recorded in the desorption format. This procedure is repeated for each sample analyzed during the drilling of the well.

\section{Results and Discussion}

Table I shows the results of the 8 samples for gas in surrounding strata taken from $7 \mathrm{CBM}$ wells drilled in 6 municipalities in the Cundiboyacan highlands in the Guaduas formation (Figure 1). Each sample has gas content and depth, the lost, measured and residual gases of the sample are reported separately and as a total sum. The total gas is presented in $\mathrm{ft}^{3} /$ ton and $\mathrm{m}^{3} /$ ton $\left(\mathrm{cm}^{3} / \mathrm{g}\right)$. The last column shows the average reflectance of the vitrinite (Ro). 
Table I: Results of measurement of lost, measured, residual and total gas, and of reflectance of the vitrinite (Ro) for 8 samples of lodolites (shales) in the formation of guaduas.

\begin{tabular}{|c|c|c|c|c|c|c|c|c|c|}
\hline ID Sample & Municipality & Well & $\begin{array}{c}\text { Depth } \\
\text { (m) }\end{array}$ & $\begin{array}{l}\text { Lost gas } \\
\text { (ft }{ }^{3} / \text { ton) }\end{array}$ & $\begin{array}{c}\text { Measured } \\
\text { gas ( } \mathrm{ft}^{3} / \text { ton) }\end{array}$ & $\begin{array}{c}\text { Gas } \\
\text { residual } \\
\text { (ft'ton) }\end{array}$ & $\begin{array}{c}\text { Gas Total } \\
\text { (ft } \mathrm{ft}^{3} / \text { ton) }\end{array}$ & $\begin{array}{c}\text { Gas } \\
\text { total } \\
\text { (mlton) }\end{array}$ & $\begin{array}{c}\text { Vitrinite } \\
\text { reflectanc } \\
\text { e }\left(\mathbf{R}_{0}\right)\end{array}$ \\
\hline C8-98 & Sutatausa & Sutatausa 1 & 398 & 0 & 9,96 & - & 9,96 & 0,28 & 0,68 \\
\hline C3-183 & Cucunuba & Cucunuba 3 & 231 & 0 & 3,64 & 10,67 & 14,31 & 0,40 & 0,73 \\
\hline PS2-29 & Samacá & Samacá 2 & 321 & 23,94 & 16,19 & - & 40,13 & 1,13 & 0,85 \\
\hline PR1-38 & Ráquira & Ráquira 1 & 140 & 0,48 & 24,65 & - & 25,31 & 0,71 & 0,75 \\
\hline PSOC1-5 & Socotá & Socotá 1 & 306 & 0,34 & 1,18 & 14,40 & 16,22 & 0,46 & 1,32 \\
\hline PSOC2-6 & Socotá & Socotá 2 & 509 & 0,00 & 0,08 & 21,79 & 21,87 & 0,62 & 1,36 \\
\hline PCHI1-12 & Chinavita & Chinavita 1 & 475 & 1,36 & 34,30 & 14,58 & 50,24 & 1,42 & - \\
\hline PHUM1-14 & Chinavita & Chinavita 1 & 513 & 9,17 & 21,19 & 13,25 & 43,61 & 1,24 & - \\
\hline
\end{tabular}

Below are the calculations of lost, measured and residual gas for one of the eight samples analyzed (Chinavita well 1, sample PCH1-12).

\section{Sample PCHI1-12 (Pozo chinavita 1)}

Initially the gas lost was measured, then the gas measured and finally the residual gas. For each gas measurement, the following were measured and recorded: date, temperature, pressure and gas content, because these are necessary for the standardized gas content (SCF) of the desorbed gas in $\mathrm{ft} 3 /$ ton and $\mathrm{m} 3 /$ ton [10].

Figure 3 (left) represents the lost gas procedure using the first day's measurements. The calculation of the lost gas is done using a linear regression to calculate the amount of gas that was lost from the time the drill bit touched the coal seam to the time the tank was sealed. The intersection of the regression line with the Y-axis corresponded to $1,365 \mathrm{ft} 3 /$ ton. Figure 3 (right) presents the results of the gas measured over a three month period. The behavior of the cumulative measured gas curve shows good desorption at first to gradually decrease to zero. The accumulated measured gas value is $34.30 \mathrm{ft} 3 /$ ton. The residual gas calculation was $14.58 \mathrm{ft} 3 / \mathrm{ton}$. After adding lost, measured and residual gas, the total gas for that sample is $50.24 \mathrm{ft} 3 /$ ton (Table I).
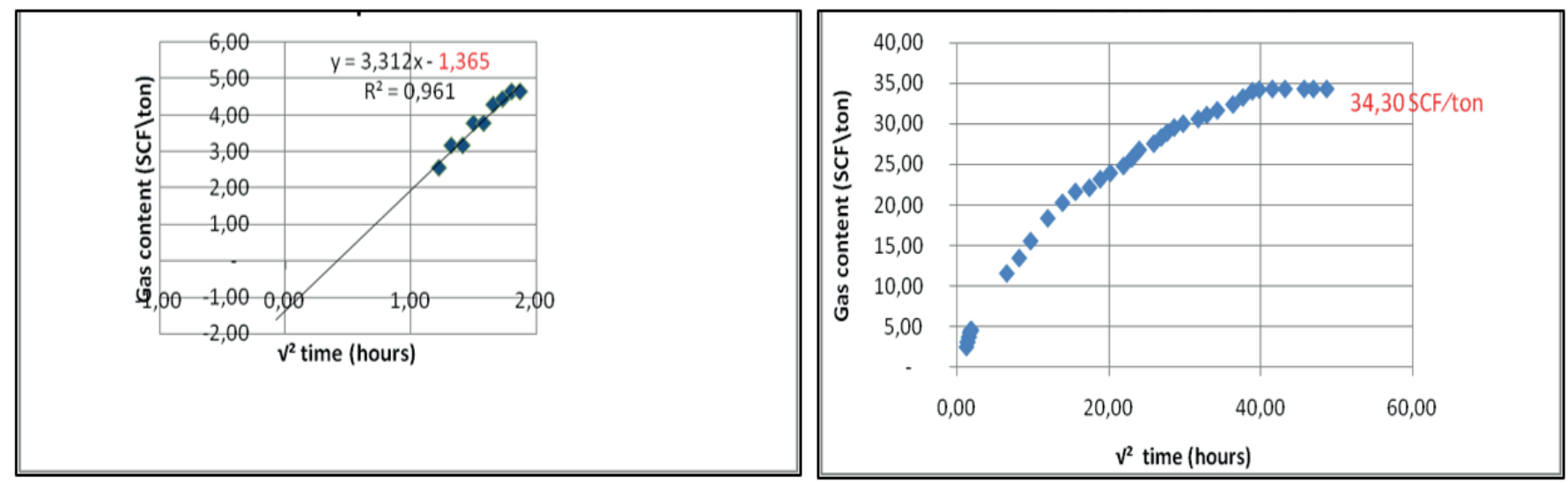

Figure 3. Left, linear regression to calculate the value of the gas lost. Right, desorbed gas curve representing the sum of all measured gas measurements over a 3 month period. Sample PCh 1-12 from Chinavita Well 1. 
This research is a pioneer in calculating emissions from rocks surrounding coal, and aims to demonstrate that gas contents in rocks close to coal in CBM exploration serve as a basis for calculating emissions from rock mass subsidence as a result of coal extraction (Figure 4).

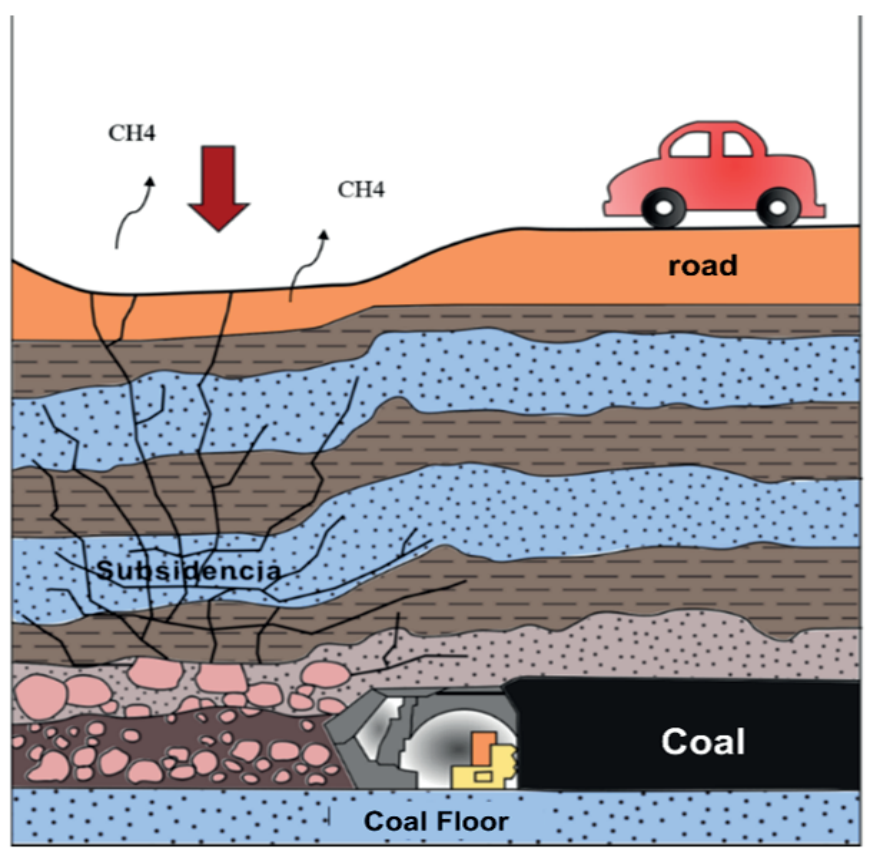

Figure 4. Methane emissions from the surrounding rock into the coal from subsidence caused by mining.

Of the eight samples analyzed from surrounding rocks (Table I), the Samaca 2 and Chinavita 1 wells produced the highest gas content of 40.13 and $50.24 \mathrm{ft}^{3} / \mathrm{ton}$ respectively, this despite the fact that residual gas was not measured in the Samaca 2 well samples. Lower gas contents (9.96 and $14.31 \mathrm{ft}^{3} /$ ton) were observed in the Sutatausa 1 and Cucunuba 3 wells. The total gas, with approximately $50 \%$ residual gas, provides the highest percentage that may indicate low permeability (Table I). Therefore, if the residual gas in the Samaca and Raquira wells were calculated, the total content could be around $50 \mathrm{ft} 3 /$ ton. That gas content would be close to the gas content found in some of the North American shales such as the New Albany [16]. The main gas contents were expected in the Socota wells because they were coking coal with vitrinite reflectance greater than $1 \%$, but this was not the case because the total content did not exceed $22 \mathrm{ft}^{3} /$ ton. For coking coal, the vitrinite reflectance is above $1 \%(1.32-1.36 \%)$ [4], [9].

The samples presented in Table I are not the only ones analyzed because samples were also taken in front of the mine, but they were not included in this investigation because they were not cores. For each well, 2 or 3 mudstone samples were processed at different depths. The information has been consolidated in Table II, by average gas content, by municipality and by depth. In the Sutatausa well, with samples taken at depths ranging from 100 to $400 \mathrm{~m}$, the average gas content was about $9.96 \mathrm{ft}^{3} /$ ton; in Cucunubá, between 200 and $300 \mathrm{~m}$ deep, the gas values were 14.31 to $14.33 \mathrm{ft}^{3} /$ ton; in Ráquira between 100 and $150 \mathrm{~m}$ deep, the gas values were between 10.79 and $15.13 \mathrm{ft}^{3} /$ ton; in Samacá at a depth of about 100 $\mathrm{m}$, the values reached $19.41 \mathrm{ft} 3 /$ ton; in Socotá at depths between 300 and $500 \mathrm{~m}$, the gas content was between 5.4 and $39.14 \mathrm{ft}^{3} / \mathrm{ton}$; and in Chinavita at depths between 400 and $500 \mathrm{~m}$, the values were between 50.24 and $43.61 \mathrm{ft}^{3} /$ ton (Table II).

Table II. Average gas content in the rocks surrounding the coal vs. depth of the guaduas formation.

\begin{tabular}{|c|r|r|r|r|r|r|}
\hline \multirow{2}{*}{ Prof. (m) } & \multicolumn{5}{|c|}{ Total gas content (ft'/ton) in the pits: } \\
\hline & Sutatausa & Cucunuba & \multicolumn{1}{|c|}{ Ráquir'a } & Samacá & \multicolumn{1}{c|}{ Socotá } & Chinavita \\
\hline $\mathbf{1 0 0}$ & & & 10,79 & 19,41 & & \\
\hline $\mathbf{1 5 0}$ & & & 15,13 & & & \\
\hline $\mathbf{2 0 0}$ & & 14,31 & & & & \\
\hline $\mathbf{3 0 0}$ & & 14,33 & & & & \\
\hline $\mathbf{4 0 0}$ & 9,96 & & & & & 50,24 \\
\hline $\mathbf{5 0 0}$ & & & & & 5,40 & 43,61 \\
\hline $\mathbf{7 0 0}$ & & & & & 39,14 & \\
\hline
\end{tabular}

The highest contents were found in Chinavita at depths exceeding $400 \mathrm{~m}$; therefore, depth appears to be a key factor in gas content because, on average, gas content increases with depth. For example, in the Socota 2 well at about $500 \mathrm{~m}$ depth, the content reached $21.87 \mathrm{ft}^{3} /$ ton, and in the Chinavita 1 well at $475 \mathrm{~m}$ depth the gas content reached $50.24 \mathrm{ft}^{3} /$ ton, in both cases the majority of the gas is measured gas (Table I).

As mentioned above, samples were also collected from mine faces. These contents were relatively low and did not exceed $15 \mathrm{ft}^{3} /$ ton. The gas content in shale samples taken at depths of $500 \mathrm{~m}$ ranged from 10 to $50 \mathrm{ft}^{3} /$ ton (Table I), which is lower than that found in the coal seams of the same wells that have reached $300 \mathrm{ft}^{3} /$ ton [7]. In many of the samples from Cucunuba, Socotá and Chinavita, a large percentage of the total gas corresponds to residual 
gas, which could be indicating low permeability (Table I).

With the methodology described above, the emission measurements are assumed to be equivalent to the calculation of gas reserves in the rocks surrounding the coal; and this calculation is made by multiplying the volume of the rock by the density of the rock, and by the gas content of the desorption test or total gas (Table I) [2]. The volume of gas is multiplied by the density of the methane to convert the emissions to tonnes, which is how greenhouse gases are reported [1].

No isotope or desorption isotope tests were performed for these samples. For now, it is only possible to associate the gas content with the vitrinite reflectance. The vitrinite reflectance (Ro), which indicates the maturation of organic matter and the thermal transformation of the kerogen, was found in all samples. In most samples, Ro below $1 \%$ indicates that there is not enough thermal maturation to produce thermogenic gas; the only exception is in Socotá, where the reflectance of the vitrinite is approximately $1.3 \%$ which places it in the range of condensate formation. The highest gas content was found in Chinavita (Table I), but Ro was low, around $0.68 \%$; this could be explained by the possible influence of gas of biogenic origin [16].

The percentage of methane in these samples is unknown, but chromatography in CBM samples of the same formation indicates that the percentages of methane are close to $85 \%$. Similarly, saturation percentages are not known because the adsorption isotherm test has not been performed, but in CBM samples associated with shales (mudstones), saturation percentages of around $30 \%$ were found [4]. The gas content in coal-producing formations is not only important from an energy point of view as an unconventional hydrocarbon potential, but also for emission reporting and mine explosion prevention. From an environmental point of view, desorption tests are important for calculating and reporting greenhouse gases required as part of the 2015 climate change agreement in Paris according to IPCC standards [3]. From the mining point of view, in tunnels and other mining works, it is necessary to know the gas content of the rocks above and below the coal layers for safety reasons.

If the results are analyzed from the perspective of shale gas, the findings in the Guaduas formation confirm the hypothesis that this formation could be a proxy for older and deeper formations. In the main Cretaceous shales of Colombia such as La Luna, Macanal, Paja, Chipaque, Olini, etc., where the TOC contents are approximately $2 \%$, indicating a good quality of kerogen. As these shales are deeper than the Guaduas formation, Ro values are approximately $1.5 \%$, and from these values it would be expected that the gas content would be $50 \mathrm{ft}^{3} /$ ton or higher [17].

\section{Conclusions}

Gas contents in rocks close to coal can serve as an indicator for calculating emissions from rock mass subsidence, which occur as a result of underground coal mining. Gas contents in rocks surrounding coal seams can also be used to calculate the risk of methane gas explosions in surrounding rocks during coal mining.

The gas contents of the surrounding rocks, and therefore the emissions, are lower than those found in coal at the same depth. The areas with the highest values of gas content in the surrounding rocks are Samacá and Chinavita, with contents between 40 and $50 \mathrm{ft} 3 /$ ton. These values correspond to a third or a quarter of those obtained from the coals near these samples. The highest gas contents did not correspond to the highest range zone of the coals (Socotá), which would be explained by the intense folding and fracturing of that zone.

The gas contents found in the shales of the Guaduas formation can also be used as an indicator (proxy) for older and deeper formations that could have a good gas shale potential such as La Luna, Macanal, Paja, Chipaque, Olini, etc.

\section{References}

[1] IPCC, "Refinement to the 2006 IPCC Guidelines for National Greenhouse Gas Inventories", 2019. Disponible en: https://www.ipcc-nggip.iges. or.jp/public/2019

[2] J. Mariño and R. Chanci, "Gases de efecto invernadero: propuesta de cálculo del factor de emisiones de gas metano procedente de la 
extracción del carbon colombiano", Editorial UPTC, pp. 82, 2019.

[3] IPCC, "Volume 2 Energy - 2019 Refinement to the 2006 IPCC Guidelines for National Greenhouse Gas Inventories". Kyoto, Japan, 2019. Disponible en: https://www.ipcc-nggip. iges.or.jp/public/2019rf/vol2.html

[4] J. Mariño, A. Castro, A. Ángel, D. Granados and C. Acuña. "Gas asociado al carbón- Geología, Contenidos, Reservas, Minería y Posibilidades en Colombia". (Primera edición) Tunja, Colombia: Editorial UPTC, 2015.

[5] UPME - Consorcio EG Metano. "Estrategias para el aprovechamiento del gas metano asociado a los mantos de carbón en explotaciones bajo tierra". Bogotá, Colombia. 2016. Disponible en: http:// www1.upme.gov.co/simco/Cifras- sectoriales/ Estudios Publicaciones/Estrategias _para_el_ aprovechamiento_del_Gas_Metano.pdf

[6] IDEAM-PNUD. "Inventario nacional de gases de efecto invernadero". IDEAM, Bogotá. 2016. Disponible en: https://www.co.undp. org/content/colombia/es/home/presscenter/ articles/2016/11/03/ideam-y-pnud-presentaninventario-nacional-de-emisiones-de-gases-deefecto-invernadero.html

[7] SGC-UPTC. "Exploración gas metano asociado al carbón GMAC. Área Checua-Lenguazaque. Sector Boquerón de Tausa-La Pluma, Cucunubá". Biblioteca UPTC,. 2011.

[8]SGC-UPTC. "Exploraciónderecursosenergéticos, la exploración de gas metano asociado al carbón (GMAC o CBM) en un polígono de $200 \mathrm{~km} 2$, en los municipios de Guachetá, Ráquira y Samacá en los departamentos de Cundinamarca y Boyacá. Proyecto de investigación conjunta entre el Servicio Geológico Colombiano SGC y la Universidad Pedagógica y Tecnológica de
Colombia UPTC”. Biblioteca UPTC, 2012.

[9] SGC-UPTC. "Exploración gas metano asociado al carbón. área Tasco-Socotá". UPTC-sede Sogamoso. Biblioteca UPTC, 2013.

[10] SGC-UPTC. "Exploración Gas Metano Asociado al Carbón. Área Úmbita-Rondón". Bogotá, diciembre de 2014. Biblioteca UPTC, 2014.

[11] ANH - EAFIT. "Valoración del potencial exploratorio CBM en la cuenca carbonífera de Amagá y Boyacá-Cundinamarca". Biblioteca ANH, Bogotá. 2011.

[12] UPME. "Recursos y reservas geológicas del carbon colombiano". UPME Bogotá. 2019. Disponible en: http://www.upme.gov.co/guia_ ambiental/carbon/areas/zonas/indice.htm

[13] J. Mariño and E. Amaya. "Lithofacies cyclicity determination in the Guaduas formation (Colombia) using Markov chains". Earth Sciences Research Journal, vol. 20, no. 3, pp. 1-9, 2016.

[14] A. Pardo and G. Camargo, "Deformación asociada a la Falla de Soapaga en el área entre Paz del Río y Corrales (Boyacá), nuevas interpretaciones a partir del modelamiento de Trishear". Poster, XVII Congreso Colombiano de Geología. 2019. Disponible en: https://www. researchgate.net/publication/324077513_Area Cordillera_Oriental_-_Prospectivity_Report

[15] W. P. Diamond and S. Schatzel, "Measuring the gas content of coal: A review", International Journal of Coal geology, vol. 35, pp. 311-331, 1998.

[16] M. Mastalerz, A. Schimmelmann, A. Drobniak and Y. Chem, "Porosity of Devonian New Albany shale across a maturation gradient: Insight from 
organic petrology, gas adsorption, and mercury intrusion", AAPG Bulletin, vol. 97, no. 10, pp. 1621-1643, 2013.

[17] ANH-AYCO. "Análisis especiales (desorción, cromatografía, isotermas). en: levantamiento, descripción, muestreo y caracterización geoquímica, petrofísica y bioestratigráfica de 2000m (6560') de secuencias finas del ciclo cretácico de la Cordillera Oriental, Valle del Magdalena y Catatumbo”. Bogotá. ANH, 2014. 